\title{
PERAN AUDIT MANAJEMEN SUMBER DAYA MANUSIA TERHADAP KINERJA KARYAWAN INSTALASI RAWAT INAP DI RUMAH SAKIT

\author{
(Studi Kasus pada Rumah Sakit Umum Daerah Dr. Soedirman Kebumen)
}

\author{
Susi Astuti, S.E., M.Ak.,Ak., CA
}

\begin{abstract}
The development of hospital management, both from management and operational aspects is strongly influenced by various demands from the environment and technological progress, including the need for internal and external examination. Various problems arise along with hospital demands that must always improve its services, such as government regulations, financial management policies, the accuracy of information systems, the use of information technology, the adequacy of capital and Human Resources.

The effectiveness and efficiency of health services such as care, treatment, examination, medical treatment, and other good diagnostics will affect patient satisfaction levels in the hospital. The management of the hospital is required to be able to plan, mobilize, organize, and coordinate the activities of professional and non-professional workers.

The role of human resource functions towards the achievement of overall organizational goals will require an assessment and evaluation of the implementation of human resource programs developed in the function of each human resource. Assessment and evaluation conducted to find out all planned programs whether the implementation is maximal or not If indeed in practice has not been implemented with the maximum, it will look for solutions to overcome these problems. One way to assess this is to carry out management audits on human resource functions.
\end{abstract}

Keywords: Management Audits, Human Resources, performance 


\section{PENDAHULUAN}

\section{Latar Belakang Masalah}

Pesatnya perkembangan ilmu pengetahuan dan teknologi membuat organisasi harus mampu beradaptasi dengan perubahan, baik perubahan yang berasal dari dalam maupun luar organisasi. Kemampuan organisasi menghadapi perubahan akan berdampak pada kelangsungan hidup organisasi. Rumah Sakit sebagai salah satu organisasi bentuk layanan jasa yang kompleks, dinamis, kompetitif, padat modal, padat karya, dan multi disiplin. Rumah Sakit juga mempunyai misi memberikan pelayanan kesehatan kepada masyarakat yang bermutu dan terjangkau. Dalam menghadapi perubahan, Rumah Sakit harus tetap konsisten menjalankan misi sebagai institusi pelayanan sosial di bidang kesehatan, dapat berkembang, mandiri, dan memiliki daya saing yang tinggi.

Keberadaan manajemen sumber daya manusia sangat penting bagi organisasi dalam mengelola, mengatur, mengurus, dan menggunakan sumber daya manusia yang tersedia sehingga dapat berfungsi secara efektif dan efisien. Bagi organisasi, sumber daya manusia merupakan aset berharga sehingga membutuhkan pengelolaan dan pemeliharaan yang baik. Hal ini dikarenakan sumber daya manusia akan berpengaruh pada sumber daya lain dalam organisasi.

Sumber daya manusia menjadi sangat penting seiring dengan kemajuan yang terjadi di era globalisasi dalam sebuah perusahaan atau organisasi. Sumber daya manusia merupakan sebuah asset utama bagi perusahaan karena merupakan faktor utama dalam pengelolaan tujuan suatu perusahaan. Keberadaan manajemen sumber daya manusia inilah yang nantinya akan berperan penting dalam suatu perusahaan atau organisasi dalam hal mengelola, mengatur, mengurus dan menggunakan sumber daya manusia yang tersedia dengan maksimal sehingga dapat berfungsi secara efektif dan efisien sesuai dengan yang diharapkan. Selain itu, mereka juga mempunyai perasaan, pendidikan, latar belakang, dan pikiran yang berbeda-beda antara yang satu dengan yang lain yang nantinya akan dibawa ke lingkungan kerja

Mengingat pentingnya peran fungsi sumber daya manusia terhadap pencapaian tujuan organisasi secara keseluruhan, maka diperlukan suatu penilaian dan pengevaluasian terhadap pelaksanaan program-program sumber daya manusia yang dikembangkan pada fungsi masingmasing sumber daya manusia itu sendiri. Penilaian dan pengevaluasian yang dilakukan ini untuk mengetahui seluruh program yang direncanakan apakah pelaksanaannya sudah maksimal atau belum. Jika memang pada prakteknya belum dilaksanakan dengan maksimal maka akan dicari solusi untuk mengatasi permasalahan tersebut. Salah satu cara untuk menilai hal 
tersebut adalah dengan melaksanakan audit manajemen pada fungsi sumber daya manusia.

Audit internal secara umum bertujuan untuk memeriksa kesesuaian antara aktivitas yang dijalankan dengan kebijakan atau prosedur yang telah ditetapkan oleh manajemen. Menurut Zamzani (2017:2) Satuan Kerja Auditor Internal (SKAI) melakukan pemeriksaan dan evaluasi atas kecukupan dan efektivitas pengendalian internal dengan tujuan untuk menentukan apakah sistem yang telah ditetapkan dapat diandalkan untuk memberikan keyakinan bahwa tujuan dan sasaran organisasi dapat dicapai secara efektif dan efisien.

Audit sumber daya manusia menekankan penilaian terhadap segala aktivitas sumber daya manusia yang terjadi dalam suatu organisasi, penilaian ini bertujuan untuk memastikan apakah aktivitas di dalam organisasi tersebut berjalan secara efektif dan efisien. Oleh karena itu, penilaian dengan melakukan audit sumber daya manusia dapat menilai proses atau aktivitas yang belum sesuai dengan kebijakan organisasi dan persyaratan hukum, sehingga dapat meminimalisir proses internal organisasi yang berpotensi melanggar hukum. Manfaat paling penting dari audit sumber daya manusia adalah membantu organisasi untuk mengidentifikasi kondisi yang terjadi saat ini, serta langkah yang perlu dilakukan untuk meningkatkan efektifitas fungsi kerja karyawan dalam suatu organisasi tersebut.

Objek penelitian yang dijadikan sebagai tolak ukur untuk menilai aktivitas sumber daya manusia ini nantinya akan dilakukan di RSUD Dr. Soedirman Kebumen. Alasan untuk memilih objek rumah sakit dikarenakan pada saat ini bidang kesehatan terus mengalami peningkatan baik secara kualitas maupun kuantitas seiring dengan berkembangnya ilmu dan teknologi yang semakin canggih. Hal ini membuat instansi atau pihak yang berhubungan dengan kesehatan salah satunya rumah sakit tumbuh dengan pesat. Begitu juga halnya dengan RSUD Dr. Soedirman yang sampai saat ini belum pernah dilakukan penelitian terkait audit manajemen sumber daya manusia.

Penelitian tentang audit manajemen sumber daya manusia ini akan berfokus pada aktivitas-aktivitas yang dilakukan oleh sumber daya manusia, implementasi kebijakan yang sudah ditetapkan oleh manajemen dan tingkat kepatuhan terhadap kebijakan manajemen, sehingga dapat dilihat seberapa besar peran audit manajemen terhadap sumber daya manusia. Tujuannya adalah untuk mengetahui kinerja dari karyawan, khususnya Instalasi Rawat Inap di RSUD Dr. Soedirman.

Bagian Kepegawaian bertugas mengelola, meningkatkan kinerja karyawan 
dan memonitori kegiatan serta kebutuhan karyawan dalam rumah sakit supaya tercipta suasana yang harmonis di lingkungan kerja. Penyimpangan bisa terjadi saat bekerja, kondisi lingkungan kerja yang tidak kondusif, fungsi-fungsi manajemen sumber daya manusia tidak berjalan dengan baik. Masalah tersebut dapat menyebabkan kinerja karyawan rumah sakit mulai terganggu.

Dilihat dari kondisi masyarakat saat ini sering muncul permasalahan dalam hal kesehatan. Pelayanan rawat inap yang cenderung terlambat dalam menanganinya menjadi permasalahan yang sangat sering dialami oleh masyarakat. Kedisiplinan karyawan menjadi penilaian yang penting untuk menilai kinerja dari rumah sakit tersebut. Pelayanan yang berkualitas dari rumah sakit sangatlah diperlukan oleh masyarakat. Selain pelayanan yang berkualitas dapat dilihat juga dari kinerja karyawan rumah sakit yang baik, serta didukung dengan fasilitas yang menunjang setiap pekerjaan dalam melakukan pelayanan terhadap masyarakat.

Perusahaan menghadapi berbagai risiko dalam mencapai tujuan dan sasaran yang telah ditetapkannya. Oleh karena itu, perusahaan harus melakukan pengendalian untuk menghadapi dan mengelola risiko tersebut. Pengendalian yang lemah akan mengakibatkan kerugian, skandal, kegagalan, dan merusak reputasi organisasi dalam berbagai hal. Jika risiko dibiarkan saja tanpa adanya media pengendali risiko, hal tersebut akan menjadi permasalahan perusahaan dalam mencapai tujuannya.(Zamzani 2017: 70).

Berdasarkan uraian diatas maka sangatlah penting bagi pihak manajemen untuk mengevaluasi kembali hal-hal yang menyebabkan masyarakat merasa kurang puas terhadap kinerja karyawan rumah sakit. Untuk mencapai tujuan tersebut, kinerja yang baik dari para karyawan rumah sakit sangat mempengaruhi kualitas pelayanan rumah sakit. Jika kinerja para karyawan baik, maka hal tersebut akan berpengaruh positif pada kinerja rumah sakit. Oleh karena itu, penulis melakukan penelitian untuk mengetahui pengaruh audit manajemen sumber daya manusia terhadap kinerja karyawan.

Faktor penting dalam pengendalian adalah manusia. Manusia dapat membuat sistem bekerja dengan buruk, manusia dapat membuat sistem yang baik menjadi gagal dijalankan. Tindakan personel, manajer, dan karyawan menentukan kesuksesan perusahaan. Oleh karena itu, sangat penting bagi organisasi untuk memotivasi staf agar menjalankan pengendalian dengan melibatkannya dalam proses identifikasi dan perancangan pengendalian. (Agoes 2017: 105).

Penelitian tentang audit sumber daya manusia ini difokuskan untuk menilai 
aktivitas-aktivitas yang terdapat pada fungsi sumber daya manusia di RSUD Dr. Soedirman Kabupaten Kebumen agar rumah sakit bisa tetap menjaga maupun meningkatkan kinerja dari para karyawannya.

\section{KAJIAN PUSTAKA}

\section{Pengertian Kinerja}

Menurut Fahmi (2016: 137) Kinerja adalah hasil yang diperoleh oleh suatu organisasi baik organisasi tersebut bersifat profit oriented dan non profit oriented yang dihasilkan selama satu periode waktu.

Kinerja karyawan merupakan salah satu faktor penentu keberhasilan perusahaan atau organisasi dalam mencapai tujuannya. Kinerja dari para karyawan harus mendapat perhatian dari para pimpinan perusahaan karena menurunnya kinerja dari karyawan dapat mempengaruhi kinerja perusahaan secara keseluruhan.

Ukuran kinerja dapat dilihat dari sisi jumlah dan mutu tertentu sesuai standar organisasi atau perusahaan. Hal itu sangat terkait dengan fungsi organisasi atau pelakunya. Bentuknya dapat bersifat tangible dan intangible, tergantung kepada bentuk dan proses pelaksanaan pekerjaan itu sendiri. Kinerja dapat dilihat dari proses, hasil, dan outcome.

Manajemen kinerja adalah suatu ilmu yang memadukan seni didalamnya untuk menerapkan sutu konsep manajemen yang memiliki tingkat fleksibilitas yang representatif dan aspiratif guna mewujudkan visi dan misi perusahaan dengan cara menggunakan orang yang ada di organisasi tersebut secara maksimal.

Penilaian kinerja adalah suatu penilaian yang dilakukan kepada pihak manajemen perusahaan baik para karyawan maupun manajer yang selama ini telah melakukan pekerjaaannya.

\section{Alasan Diperlukannya Penilaian Kinerja}

1. Penilaian kinerja memberikan informasi bagi pertimbangan pemberian promosi dan penetapan gaji

2. Penilaian kinerja memberikan umpan balik bagi para manajer maupun karyawan untuk melakukan introspeksi dan meninjau kembali perilaku selama ini, baik yang positif maupun negatif untuk kemudian dirumuskan kembali sebagai perilaku yang mendukung tumbuh berkembangnya budaya organisasi secara keseluruhan

3. Penilaian kinerja diperlukan untuk pertimbangan pelatihan dan pelatihan kembali serta pengembangan

4. Penilaian kinerja dewasa ini bagi setiap organisasi khususnya organisasi bisnis merupakan suatu keharusan, apalagi jika dilihat 
tingginya persaingan antar perusahaan

5. Hasil penilaian kinerja lebih jauh akan menjadi bahan masukan bagi pemerintah dalam melihat bagaimana kondisi perusahaan tersebut.

\section{Manfaat Penilaian Kinerja}

1. Mengelola operasi organisasi secara efektif dan efisien melalui pemotivasian karyawan secara maksimum

2. Membantu pengambilan keputusan yang bersangkutan dengan karyawan, seperti promosi, transfer dan pemberhentian.

3. Mengidentifikasian kebutuhan pelatihan dan pengembangan karyawan dan untuk menyediakan kriteria seleksi dan evaluasi program pelatihan karyawan

4. Menyediakan umpan balik bagi karyawan mengenai bagaimana atasan mereka menilai kinerja mereka

5. Menyediakan satu dasar bagi distribusi penghargaan

\section{Manajemen}

Menurut Malayu (2008: 9) manajemen adalah ilmu dan seni mengatur proses pemanfaatan sumber daya manusia dan sumber-sumber lainnya secara efektif dan efisien untuk mencapai suatu tujuan tertentu.
Dasar-dasar manajemen adalah sebagai berikut:

1. Adanya kerjasama diantara sekelompok orang dalam ikatan formal

2. Adanya tujuan bersama serta kepentingan yang sam yang akan dicapai

3. Adanya pembagian kerja, tugas, dan tanggung jawab yang teratur

4. Adanya hubungan formal dan ikatan tata tertib yang baik

5. Adanya human organization.

\section{Manajemen Sumber Daya Manusia}

Menurut Abdurrahmat (2006: 11) manajemen sumber daya manusia adalah proses pengendalian berdasarkan fungsi manajemen terhadap daya yang bersumber dari manusia.

\section{Tujuan Manajemen Sumber Daya Manusia}

1. Tujuan Organisasional

Ditujukan untuk dapat mengenali keberadaan manajemen sumber daya manusia dalam memberikan kontribusi pada pencapaian efektivitas organisasi.

2. Tujuan Fungsional

Ditujukan untuk mempertahankan kontribusi departemen pada tingkat yang sesuai dengan kebutuhan organisasi.

\section{Tujuan Sosial}

Ditujukan untuk secara etis dan sosial merespon terhadap kebutuhan kebutuhan dan tantangan-tantangan 
masyarakat melalui tindakan meminimalisir dampak negatif terhadap organisasi.

\section{Tujuan Personal}

Ditujukan untuk membantu karyawan dalam pencapaian tujuannya, minimal tujuan-tujuan yang dapat mempertinggi kontribusi individual terhadap organisasi.

\section{Peranan Manajemen Sumber Daya} Manusia

Menurut Malayu (2008: 15) Manajemen Sumber Daya Manusia mengatur dan menetapkan program kepegawaian yang mencakup masalahmasalah sebagai berikut:

1. Menetapkan jumlah, kualitas, dan penempatan tenaga kerja yang efektif sesuai dengan kebutuhan perusahaan berdasarkan job description, job specification, job requirement, dan job evaluation .

2. Menetapkan penarikan, seleksi dan penempatan karyawan berdasarkan asas the right man in right place and right man in the right job.

3. Menetapkan program kesejahteraan, pengembangan, promosi, dan pemberhentian.

4. Meramalkan penawaran dan permintaan sumber daya manusia pada masa yang akan datang.

5. Memperkirakan keadaan perekonomian pada umumnya dan

perkembangan perusahaan pada khususnya.

6. Memonitor dengan cermat undangundang perburuhan dan kebijaksanaan pemberian balas jasa perusahaan-perusahaan sejenis.

7. Memonitor kemajuan teknik dan perkembangan serikat buruh.

8. Melaksanakan pendidikan, latihan, dan penilaian prestasi karyawan.

9. Mengatur mutasi karyawan baik vertikal maupun horizontal.

10. Mengatur pensin, pemberhentian, dan pesangonnya.

\section{Audit Manajemen Sumber Daya Manusia}

Menurut Konrath dalam Agoes (2017: 2) Auditing adalah suatu proses sistematis untuk secara objektif mendapatkan dan mengevaluasi bukti mengenai asersi tentang kegiatan-kegiatan dan kejadian-kejadian ekonomi untuk meyakinkan tingkat keterkaitan antara asersi tersebut dan kriteria yang telah ditetapkan dan mengkomunikasikan hasilnya kepada pihak-pihak yang berkepentingan.

Definisi audit internal yang dikemukakan oleh The Institute of Internal Auditor (IIA) dalam Agoes (2017:2), "Internal auditor is an independent, objective assurance and consulting activity designed to add value and improve an organization's operation. It helps an organization accomplish its objectives by bringing a systematic disciplined approach 
to evaluate and improve the effectiveness of risk management, control, and governance process"

\section{Jenis-jenis Audit}

Menurut Agoes (2017:10) ditinjau dari luasnya pemeriksaan, audit bisa dibedakan atas:

1. Pemeriksaan Umum (General Audit) Suatu pemeriksaan umum atas laporan keuangan yang dilakukan oleh KAP independen dengan tujuan untuk bisa memberikan pendapat mengenai kewajaran laporan keuangan secara keseluruhan. Pemeriksaan tersebut harus dilakukan sesuai dengan Standar Profesional Akuntan Publik atau ISA (International Standard Audit) atau Panduan Audit Entitas Bisnis Kecil dan memperhatikan Kode Etik Akuntan Indonesia, Kode Etik Profesi Akuntans Publik serta Standar Pengendalian Mutu.

2. Pemeriksaan Khusus (Special Audit) Suatu pemeriksaan terbatas (sesuai dengan permintaan auditee) yang dilakukan oleh KAP (Kantor Akuntan Publik) yang independen dan pada akhir pemeriksaannya auditor tidak perlu memberikan pendapat terhadap kewajaran laporan keuangan secara keseluruhan. Pendapat yang diberikan terbatas pada pos atau masalah tertentu yang diperiksa karena prosedur audit yang dilakukan juga terbatas.
Ditinjau dari jenis pemeriksaan, audit bisa dibedakan atas:

1. Audit Manajemen (Management Audit/Operational Audit)

Suatu pemeriksaan terhadap kegiatan operasi suatu perusahaan, termasuk kebijakan akuntansi dan kebijakan operasional yang telah ditentukan oleh manajemen untuk mengetahui apakah kegiatan operasi tersebut sudah dilakukan secara efektif, efisien, dan ekonomis. Pendekatan audit yang biasa dilakukan adalah menilai efisiensi, efektivitas, dan keekonomisan dari masing-masing fungsi yang terdapat dalam perusahaan.

2. Pemeriksaan Ketaatan (Compliance Audit)

Pemeriksaan yang dilakukan untuk mengetahui apakah perusahaan sudah mentatati peraturan-peraturan dan kebijakan-kebijakan yang berlaku, baik yang ditetapkan oleh pihak intern perusahaan (manajemen, dewan komisaris) maupun pihak eksternal (pemerintah, Bapepam LK, Bank Indonesia, Direktorat Jenderal Pajak). Pemeriksaan bisa dilakukan oleh KAP atau Bagian Internal Audit.

3. Pemeriksaan Intern (Internal Audit)

Pemeriksaan yang dilakukan oleh bagian internal audit perusahaan, baik terhadap laporan keuangan dan catatan akuntansi perusahaan, maupun ketaatan 
terhadap kebijakan manajemen yang telah ditentukan. Pemeriksaan yang dilakukan auditor internal biasanya lebih rinci dibandingkan dengan pemeriksaan umum yang dilakukan oleh KAP. Auditor internal tidak memberikan opini terhadap kewajaran laporan keuangan karena pihak-pihak diluar perusahaan menganggap bahwa auditor internal merupakan orang dalam perusahaan tidak independen. Laporan audit internal berisi temuan pemeriksaan (audit findings) mengenai penyimpangan dan kecurangan yang ditemukan, kelemahan peengendalian internal, beserta saransaran perbaikannya (recommendations).

4. Pemeriksaan Komputer (Computer Audit)

Pemeriksaan oleh KAP terhadap perusahaan yang memproses data akuntansinya dengan menggunakan Electronic Data Processing (EDP) System.

\section{Pengertian Audit Manajemen}

Menurut Agoes (2017: 11) audit manajemen adalah suatu pemeriksaan terhadap kegiatan operasi suatu perusahaan, termasuk kebijakan akuntansi dan kebijakan operasional yang telah ditentukan oleh manajemen untuk mengetahui apakah kegiatan operasi tersebut sudah dilakukan secara efektif, efisien, dan ekonomis. Pendekatan audit yang biasa dilakukan adalah menilai efisiensi, efektivitas, dan keekonomisan dari masing-masing fungsi yang terdapat dalam perusahaan.

Secara umum audit manajemen merupakan investigasi dari suatu organisasi dalam semua aspek kegiatan manajemen dari yang paling tinggi sampai dengan bawah dan pembuatan laporan audit mengenai efektifitasnya atau dari segi profitabilitas dan efisiensi kegiatan bisnisnya.

\section{Ruang Lingkup Audit Manajemen}

Menurut Bayangkara (2011: 4) ruang lingkup audit manajemen yaitu seluruh aspek kegiatan manajemen berupa seluruh kegiatan atau hanya mencangkup bagian tertentu dari aktivitas yang dilakukan. Periode audit juga bervariasi, mulai jangka satu minggu, beberapa bulan, satu tahun, atau beberapa tahun, sesuai dengan harapan yang ingin dicapai

\section{Prosedur Audit Manajemen}

Menurut Agoes (2017: 11) prosedur audit yang dilakukan dalam suatu management audit tidak seluas prosedur audit yang dilakukan dalam suatu general (financial) audit karena ditekankan pada evaluasi terhadap kegiatan operasional perusahaan.

Biasanya prosedur audit yang dilakukan mencakup:

\section{Analytical review procedures}

$$
\text { Membandingkan laporan }
$$

keuangan periode berjalan dengan 
periode yang lalu, anggaran dengan realisasinya serta analisis rasio perusahaan yang dibandingkan dengan rasio perusahaan

2. Evaluasi atas management control system

Tujuannnya antara lain untuk mengetahui apakah terdapat sistem pengendalian manajemen dan pengendalian intern (internal audit) yang memadai dalam perusahaan, untuk menjamin keamanan aset perusahaan, dapat dipercayainya data keuangan, dan mencegah terjadinya pemborosan dan kecurangan

3. Pengujian ketaatan (compliance test) Untuk menilai efektivitas dari pengendalian intern dan sistem dan sistem pengendalian manajemen dengan melakukana pemeriksaan secara sampling atas bukti-bukti pembukuan sehingga bisa diketahui apakah transaksi bisnis perusahaan dan pencatatan akuntansinya sudah dilakukan sesuai dengan kebijakan yang telah ditentukan manajemen perusahaan

\section{Tahap-tahap Audit Manajemen}

Dalam melaksanakan audit manajemen, auditor harus melakukan berbagai tahapan. Ada lima tahap dalam audit manajemen, sebagai berikut

\section{Audit Pendahuluan}

Audit pendahuluan dilakukan untuk mendapatkan gambaran mengenai objek yang diteliti dilakukan melalui penelaahan terhadap berbagai peraturan, ketentuan, dan kebijakan berkaitan dengan aktivitas yang diaudit, serta menganalisis informasi yang diperoleh untuk mengidentifikasi hal yang potensial, mengandung kelemahan pada perusahaan yang diaudit.

2. Review dan Pengujian Pengendalian Manajemen

Untuk mengevaluasi dan menguji efektivitas dari pengendalian manajemen yang terdapat di perusahaan.

\section{Audit Terinci}

Melakukan pemeriksaan terhadap transaksi perusahaan untuk mengetahui apakah proses sudah sesuai dengan kebijakan yang ditetapkan manajemen. Auditor melakukan observasi terhadap kegiatan dari fungsi yang terdapat di perusahaan.

4. Pelaporan

Tahap pelaporan betujuan untuk mengkomunikasikan hasil audit termasuk rekomendasi yang diberikan kepada pihak yang berkepentingan. Hal ini penting untuk meyakinkan pihak manajemen (objek audit) tentang hasil audit dan mendorong pihak yang berwenang untuk melakukan perbaikan terhadap kelemahan yang ditemukan. Laporan disajikan dalam bentuk komprehensif dan dalam bahasa yang 
operasional dan mudah dimengerti serta menarik untuk ditindaklanjuti.

5. Tindak lanjut

Tahap akhir dari audit manajemen, bertujuan untuk mendorong pihak yang berwenang dalam melaksanakan tindak lanjut (perbaikan) sesuai dengan rekomendasi yang diberikan.

\section{Committee of Sponsoring Organizations (COSO)}

Komisi pengawas audit internal secara internasional dibentuk pada tahun 1987 di Amerika Serikat yang diberi nama COSO (Committee of Sponsoring Organizations). Komisi pengawas ini dibentuk untuk mempelajari penyebab pelaporan keuangan yang fraud.

Komisi ini telah menyimpulkan bahwa:

1. Suatu fungsi audit internal harus ada pada tiap-tiap perusahaan public

2. Komite audit perusahaan terdiri atas nonmanagement director korporasi

Berdasarkan alasan itulah sasaran penting fungsi audit internal berfokus pada pencegahan dan pendeteksian adanya fraud untuk membantu manajemen dalam mengambil keputusan dengan pendekatan risiko (risk assesment).

\section{Control Self-Assesment (CSA)}

Control Self-Assesment

(CSA) merupakan kerangka kerja sistem pengendalian internal COSO menempatkan manusia sebagai pusat bahasan dalam topic pengendalian. Oleh karena itu, sangat penting untuk melibatkan manajemen dan personel dalam tahap-tahap diatas, manajemen dan personel mengidentifikasi risiko yang dihadapi oleh bagian atau departemennya, menilai kecukupan pengendalian yang telah dilakukannya, dan merencanakan pengembangan tindakan perbaikan yang dibutuhkan.

Control Self-Assesment (CSA) dapat dijadikan alat yang membantu manajemen melakukan proses untuk menangani isu-isu dalam arti pendekatan audit yang lebih modern. Pendekatan menggunakan Control Self-Assesment (CSA) dianggap lebbih efektif dan efisien dibandingkan dengan pendekatan audit secara tradisional.

Penerapan Control Self-Assesment (CSA) lebih komprehensif dan terfokus pada area-area yang memiiki risiko perusahaan serta menekankan pada pengendalian internal yang beroerientasi pada dapat menghasilkan berbagai informasi.

\section{Pengertian Rumah Sakit}

Rumah sakit merupakan suatu organisasi yang bersifat nirlaba (non profit oriented). Rumah Sakit sebagai salah satu organisasi bentuk layanan jasa yang kompleks, dinamis, kompetitif, padat modal, padat karya, dan multi disiplin

Menurut Undang-Undang No.44 Tahun 2009 tentang Rumah Sakit. Rumah sakit adalah institusi pelayanan kesehatan 
yang menyelenggarakan pelayanan kesehatan perorangan secara paripurna yang menyediakan pelayanan rawat inap, rawat jalan dan gawat darurat. Pelayanan kesehatan paripurna adalah pelayanan kesehatan yang meliputi promotif, preventif, kuratif, dan rehabilitatif.

Rumah Sakit mempunyai tugas memberikan pelayanan kesehatan perorangan secara paripurna. Rumah Sakit mempunyai fungsi:

1. Penyelenggaraan pelayanan pengobatan dan pemulihan kesehatan sesuai dengan standar pelayanan rumah sakit

2. Pemeliharaan dan peningkatan kesehatan perorangan melalui pelayanan kesehatan yang paripuran tingkat kedua dan ketiga sesuai kebutuhan medis

3. Penyelenggaraan pendidikan dan pelatihan sumber daya manusia dalam rangka peningkatan kemampuan dalam pemberian pelayanan kesehatan

4. Penyelenggaraan penelitian dan pengembangan serta penapisan teknologi bidang kesehatan dalam rangka peningkatan pelayanan kesehatan dengan memperhatikan etika ilmu pengetahuan bidang kesehatan.
Menurut Undang-Undang No.44 Tahun 2009 tentang Rumah Sakit Pasal 12, sumber daya manusia rumah sakit:

1. Persyaratan sumber daya manusia rumah sakit adalah harus memiliki tenaga tetap yang meliputi tenaga medis dan penunjang medis, tenaga keperawatan, tenaga kefarmasian, tenaga manajemen Rumah Sakit, dan tenaga nonkesehatan

2. Jumlah dan jenis sumber daya manusia harus sesuai dengan jenis dan klasifikasi Rumah Sakit

3. Rumah Sakit harus memiliki data ketenagaan yang melakukan praktek atau pekerjaan dalam penyelenggaraan Rumah Sakit

4. Rumah Sakit dapat mempekerjakan tenaga tidak tetap dan konsultan sesuai dengan kebutuhan dan kemampuan sesuai dengan ketentuan peraturan perundangan

\section{Klasifikasi Rumah Sakit}

Menurut Peraturan Menteri Kesehatan Republik Indonesia Nomor 56 Tahun 2014 tentang Klasifikasi dan Perijinan Rumah Sakit Pasal 11, berdasarkan jenis pelayanan yang diberikan, Rumah Sakit dikategorikan dalam Rumah Sakit Umum dan Rumah Sakit Khusus.

Rumah Sakit Umum adalah rumah sakit yang memberikan pelayanan kesehatan pada semua bidang dan jenis 
penyakit. Rumah Sakit Khusus adalah rumah sakit yang memberikan pelayanan utama pada satu bidang atau satu jenis penyakit tertentu berdasarkan disiplin ilmu, golongan umur, organ, jenis penyakit atau kekhususan lainnya.

Penetapan klasifikasi Rumah Sakit didasarkan pada:

1. Pelayanan

2. Sumber daya manusia

3. Peralatan

4. Bangunan dan prasarana

\section{Pelayanan Rawat Inap}

Menurut Peraturan Menteri Kesehatan Republik Indonesia Nomor 56 Tahun 2014 tentang Klasifikasi dan Perijinan Rumah Sakit Pasal 20, pelayanan rawat inap harus dilengkapi dengan fasilitas sebagai berikut:

1. Jumlah tempat tidur perawatan kelas III paling sedikit $30 \%$ (tiga puluh persen) dari seluruh tempat tidur untuk Rumah Sakit milik Pemerintah

2. Jumlah tempat tidur perawatan kelas III paling sedikit 20\% (dua puluh persen) dari seluruh tempat tidur untuk Rumah Sakit milik Swasta

3. Jumlah tempat tidur perawatan intensif sebanyak 5\% (lima persen) dari seluruh tempat tidur untuk Rumah Sakit milik Pemerintah dan Rumah Sakit milik Swasta

Penelitian Terdahulu
Penelitian terdahulu melakukan pengujian terkait dengann pengaruh dan peranan audit internal terhadap pelayanan rumah sakit

\section{Ringkasan Peneliti Terdahulu}

Yohansen D. Saragih (2003) dalam Peranan Audit Operasional Dalam Mendorong Efektivitas Pelayanan Kesehatan Unit Gawat Darurat Di Rumah Sakit (Studi Kasus Pada Perjan RS Dr. Hasan Sadikin) menunjukkan bahwa independensi auditor yang melakukan audit operasional atas pelayanan kesehatan pada Unit Gawat Darurat sudah memadai, auditor operasional telah memiliki kemampuan professional yang memadai, program audit untuk kegiatan pelayanan kesehatan di Unit Gawat Darurat sudah memadai, pelaksanaan audit operasional cukup memadai dan pelayanan kesehatan di Unit Gawat Darurat sangat memadai.

Divianto (2010) dalam Peranan Audit Operasional Terhadap Efektivitas Pelayanan Kesehatan Rawat Inap Di Rumah Sakit (Studi Kasus Pada Rumah Sakit Bunda Palembang) menunjukkan bahwa audit operasional dilakukan oleh auditor yang independen dan kompeten, program audit untuk pelayanan kesehatan rawat inap sudah memadai.

Riska Agustin Widya Pradana dan Nurul Fachriyah (2010) dalam Audit Manajemen Untuk Menilai Efektivitas Fungsi Sumber Daya Manusia (Studi Kasus 
Pada Rumah Sakit Islam Aisyiyah Malang) menunjukkan bahwa sepuluh fungsi sumber daya manusia yang ada, sembilan diantaranya telah berjalan efektif, yaitu Perencanaan SDM, Prosedur dan Proses Rekrutmen, Seleksi SDM, Orientasi dan Penempatan, Pelatihan dan Pengembangan SDM, Penilaian Prestasi Kerja, Manajemen Sistem Kompensasi, Perlindungan Tenaga Kerja, dan Perlindungan Tenaga Kerja. Satu fungsi yang belum efektif adalah fungsi Perencanaan danPengembangan Karir karena kebijakan yang ada belum direalisasikan.

Rezky Retno Arvianita (2015) dalam Pengaruh Audit Operasional dan Pengendalian Internal Terhadap Efektivitas Pelayanan Kesehatan Pada Rumah Sakit (Studi Kasus Pada Rumah Sakit Umum Queen Latifa Yogyakarta) menunjukkan bahwa audit operasional berpengaruh positif dan signifikan terhadap efektivitas pelayanan kesehatan, pengendalian internal berpengaruh positif dan signifikan terhadap efektivitas pelayanan kesehatan, audit operasional dan pengendalian internal secara simultan berpengaruh positif dan signifikan terhadap efektivitas pelayanan kesehatan

\section{Hipotesis}

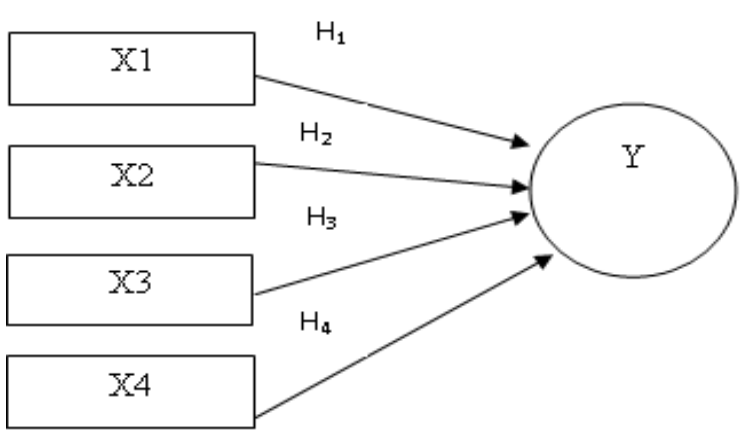

Pengembangan hipotesis pada penelitian ini:

H1: Kualifikasi Auditor berpengaruh positif terhadap kinerja karyawan

H2: Program Audit berpengaruh positif terhadap kinerja karyawan

H3: Pelaksanaan Kegiatan Audit berpengaruh positif terhadap kinerja karyawan.

H4: Tindak lanjut kegiatan audit berpengaruh positif terhadap kinerja karyawan.

\section{METODOLOGI PENELITIAN}

\section{Metode Penelitian}

Metode penelitian yang digunakan dalam penelitian ini menggunakan metode deskriptif analisis. Metode deskriptif analisis merupakan suatu cara mengumpulkan dan menyajikan data yang disertai dengan analisis yang relevan sehingga dapat memperjelas gambaran mengenai objek yang diteliti. 


\section{Objek Penelitian}

Objek penelitian dilaksanakan di RSUD Dr. Soedirman Kebumen

\section{Sumber Data}

Sumber data yang akan digunakan dalam penelitian ini adalah:

1. Data Primer

Data primer adalah data yang diperoleh secara langsung dari RSUD Dr. Soedirman Kebumen yang mencakup data yang berhubungan dengan masalah pokok pembahasan yang akan diteliti serta informasi tentang gambaran umum mengenai audit internal sumber daya manusia. Data diperoleh dengan cara menyebarkankan kuesioner, wawancara lisan dan tulisan, dan mengamati secara langsung aktivitas yang dilakukan oleh karyawan Instalasi Rawat Inap.

2. Data Sekunder

Data yang diperoleh dari berbagai buku dan literatur yang dapat mendukung serta dapat melengkapi dari masalah pokok pembahasan yang diteliti. Data diperoleh dengan cara mempelajari SPO (Standar Prosedur Operasional), kebijakan-kebijakan terkait pelayanan Instalasi Rawat Inap, struktur organisasi, jumlah karyawan di Instalasi Rawat Inap, jenis-jenis layanan di Instalasi Rawat Inap, dan data-data lainnya.

\section{Teknik Pengumpulan Data}

Teknik pengumpulan data yang dilakukan adalah dengan cara:

1. Riset Lapangan (field research)

Pada teknik ini penelitian dilakukan melalui:

a. Wawancara, yaitu proses interaksi dengan mengajukan pertanyaanpertanyaan, baik secara lisan maupun tertulis terkait dengan permasalahan yang akan diteliti. Sasaran dari wawancara ini adalah karyawan yang bekerja di Instalasi Rawat Inap pada khususnya dan karyawan unit terkait pada umumnya. Pengumpulan data dengan melakukan tanya jawab langsung dilakukan kepada orangorang yang memiliki kompetensi terkait permasalahan yang akan diteliti.

b. Kuisioner, yaitu seperangkat pertanyaan yang akan diberikan kepada karyawan yang bekerja di Instalasi Rawat Inap. Kuesioner didesain sehingga respon negatif akan mengindikasikan kelemahan pengendalian internal

c. Observasi, yaitu melakukan pengamatan secara langsung pada objek penelitian untuk memperoleh data yang dibutuhkan.

2. Riset Kepustakaan (library research) 
Teknik pengumpulan data yang dilakukan melalui buku-buku yang akan digunakan sebagai landasan teori dalam penelitian ini.

\section{Populasi dan Sampel}

Populasi dalam sampel ini adalah semua karyawan yang bekerja di Instalasi Rawat Inap RSUD Dr. Soedirman Kebumen Definisi Operasional Variabel Penelitian

Variabel yang digunakan dalam penelitian ini adalah:

1. Variabel bebas (independent variable) Suatu variabel yang keberadaannya tidak dipengaruhi oleh variabel lain dan merupakan faktor penyebab yang dapat mempengaruhi variabel tidak bebas.

Variabel bebas dalam penelitian ini adalah peranan audit manajemen.

2. Variabel tidak bebas (dependent variable)

Suatu variabel yang keberadaannya dipengaruhi oleh variabel sebelumnya. Variabel tidak bebas dalam penelitian ini adalah kinerja karyawan.

\section{Instrumen Penelitian}

Instrumen penelitian ini digunakan untuk menilai variabel yang diteliti. Tujuannya adalah untuk menghasilkan data kualitatif yang akurat. Instrumen yang digunakan adalah kuesioner yang berisi pertanyaan-pertanyaan yang harus dijawab oleh responden. Kuesioner dinilai dengan

menggunakan CSA (Control SelfAssesment).

\section{Teknik Analisis Data}

Teknik analisis data yang digunakan dalam penelitian ini dilakukan dengan menggunakan analisis regresi berganda. Analisis regresi berganda adalah teknik statistik melalui koefisien parameter untuk mengetahui besarnya pengaruh variabel independen terhadap variabel dependen. Pengujian terhadap hipotesis baik secara parsial maupun simultan, dilakukan setelah model regresi yang digunakan bebas dari pelanggaran asumsi klasik. Tujuannya adalah agar hasil penelitian dapat diinterpretasikan secara tepat dan efisien.

Persamaan regresi tersebut adalah sebagai berikut:

$Y=\alpha+\beta_{1} X_{1}+\beta_{2} X_{2}+\beta_{3} X_{3}+\beta_{4} X_{4}+\varepsilon$

Keterangan :

$\mathrm{Y} \quad=$ Kinerja Karyawan

$\mathrm{X}_{1}=$ Kualifikasi Auditor

$\mathrm{X}_{2}=$ Program Audit

$\mathrm{X}_{3}=$ Pelaksanaan Kegiatan Audit

$\mathrm{X}_{4}=$ Tindak Lanjut

$\alpha \quad=$ Konstanta

$\beta \quad=$ Koefisien Regresi

$\varepsilon \quad=$ Error

PEMBAHASAN

Rawat Inap di RSUD Dr. Soedirman

Kebumen 
Keberadaan RSUD dr. Soedirman diharapkan dapat membantu semua lapisan masyarakat khususnya wilayah Kabupaten Kebumen dalam memperoleh pelayanan kesehatan yang memadai. Setelah proses perpindahan gedung baru, RSUD dr. Soedirman menambah beberapa fasilitas Ruang Perawatan dan jumlah tempat tidur.

\section{Pengujian Pengendalian Organisasi}

RSUD Dr. Soedirman telah memiliki sistem pengendalian manajemen yang berfungsi untuk mengendalikan aktivitas fungsi sumber daya manusia. Sistem pengendalian manajemen dapat dilihat dari:

\section{Pelaksanaan Perencanaan Sumber Daya}

\section{Manusia}

Perencanaan Sumber Daya Manusia untuk masing-masing unit akan disesuaikan dengan beban kerja dan peraturan pemerintah. Beban kerja dihitung dari aktivitas yang dilakukan oleh rumah sakit.

Setiap karyawan sudah mengetahui visi, misi, tugas, wewenang, dan tanggungjawabnya masing-masing.

Pola ketenagaan dan pemenuhan tenaga mempertimbangkan rasio beban kerja dan standar ketenagaan. Kebutuhan tenaga tiap unit ditentukan secara mandiri atau bersama-sama. Tanggungjawab perencanaan Sumber Daya Manusia pada dasarnya terletak pada seluruh manajer yang membutuhkan Sumber Daya Manusia dan departemen Sumber Daya Manusia sebagai koordinator yang menangani bidang
Sumber Daya Manusia. Dokumen sosialisai peraturan, kebijakan, program kerja dan informasi legal tercatat lengkap dan rapi.

RSUD Dr. Soedirman memiliki tujuan yang mudah dipahami oleh semua karyawan melalui visi dan misi yang terstruktur dan tertulis dengan jelas. Komunikasi yang baik selalu dilakukan untuk melakukan koordinasi dalam menyusun rencana kerja, penjelasan mengenai aturan-aturan, pengarahan terkait dengan tugas yang akan diterima, seperti kejelasan dalam pembagian shift kerja karyawan, sehingga karyawan dapat bekerja dengan baik.

Selain itu, teknologi informasi yang baik sudah dilaksanakan dalam mendukung pekerjaan karyawan. Sistem informasi yang terintegrasi mampu mengakomodir kegiatan harian karyawan.

\section{Penyelenggaraan Fungsi Rekrutmen Sumber Daya Manusia}

Rekrutmen dilakukan apabila rumah sakit membutuhkan tenaga sesuai formasi. Seluruh calon karyawan wajib memenuhi persyaratan umum dan khusus. Kekurangan tenaga di satu unit kerja diupayakan lebih dahulu memindahkan dari unit kerja lain. Setiap tenaga kerja memiliki kesempatan sama tanpa diskrimiasi. Rumah sakit melaksanakan rekrutmen karyawan sekali setahun dengan periode yang berbeda 
untuk bagian medis dan non medis. Apabila terdapat karyawan yang mendadak keluar maka dilakukan rekrutmen dengan segera. Selain itu, juga mempertimbangkan dengan berapa anggaran yang disiapkan dalam proses rekrutmen tersebut.

Proses rekrutmen dilakukan dengan tujuan untuk menempatkan karyawan sesuai dengan latar belakang pendidikannya. Proses ini diharapkan dapat meningkatkan kinerja karyawan. Rencana kerja dibentuk sesuai dengan standar kerja yang berlaku di RSUD Dr. Soedirman, kemudian dikomunikasikan kepada karyawan, diharapkan karyawan tidak mengalami kendala dalam bekerja.

\section{Penyelenggaraan Seleksi Sumber Daya}

\section{Manusia}

Rumah sakit telah memiliki tim seleksi yang didalamnya terlibat calon karyawan. Tim seleksi memahami dengan baik persyaratan kerja dan sistem penyeleksian. Terdapat dua macam tes, yaitu tes umum diberikan sama kepada seluruh calon karyawan dan tes profesi diberikan berdasarkan jenis profesi. Apabila terdapat karyawan yang mengundurka diri secara mendadak maka akan dilakukan seleksi terbatas pada seleksi administrasi dan tes kompetensi profesi.

Prosedur seleksi di RSUD Dr. Soedirman Kabupaten Kebumen sudah dilaksanakan sesuai kebijakan. Sehubungan dengan penempatan Sumber Daya Manusia di RSUD Dr. Soedirman sudah sesuai dengan kompetensinya, sehingga karyawan mampu bekerja dengan maksimal sesuai dengan keahliannya dan mampu menempatkan diri di lingkungan kerjanya dan meningkatkan kinerja karyawan.

Pada saat tahapan seleksi yang dilakukan RSUD Dr. Soedirman, jumlah Sumber Daya Manusia menyesuaikan kebutuhan. Bagian keungan pun dilibatkan dalam proses seleksi ini. Tahapan selanjutnya adalah mengajukan hasil seleksi ke direktur.

Setelah calon karyawan dinyatakan lulus seleksi, tahapan selanjutnya adalah membuat perjanjian kontrak dengan karyawan selama satu hingga dua tahun untuk penempatan di Badan Layanan Umum Daerah (BLUD) dan kontrak enam bulan untuk tenaga kerja harian lepas. Namun, apabila dalam masa kontrak itu karyawan yang dimaksud tidak menunjukan perkembangan yang baik, maka akan ada pemutusan kontrak.

\section{Penyelenggaraan Fungsi Orientasi dan}

\section{Penempatan}

Orientasi umum dilaksanakan 2 hari meliputi visi, misi, Keselamatan dan Kesehatan Kerja Rumah Sakit (K3RS), medico legal dan hospital by law. Orientasi kerja dilaksanakan selama 3 bulan dimana orientasi ini lebih fokus pada pada profesi masing-masing karyawan baru. Hasil orientasi kerja dibuat oleh atasan karyawan dan diserahkan kepada Sub Bagian Diklat 
untuk dinilai. Karyawan baru mendapatkan pembimbing langsung dari atasan bersangkutan. Karyawan baru ditempatkan sesuai profesi, kemampuan, minat berdasarkan ijazah.

Karyawan menggunakan waktu kerja mereka dengan baik sesuai dengan aturan pembagian jam kerja yang sudah ditentukan. Fasilitas yang didapatkan karyawan memadai, seperti pelayanan kesehatan gratis, gaji sesuai UMR, cuti kerja yang diatur dalam UU Rumah Sakit serta mendapatkan jaminan keselamatan saat bekerja. Fasilitas yang diterima oleh karyawan harus diseimbangkan dengan kontribusi karyawan. Apabila kontribusi karyawan maksimal, maka mampu meningkatkan kinerja karyawan Rumah Sakit.

\section{Fungsi Pelatihan dan Pengembangan}

Diklat karyawan didasarkan pada prinsip menambah pengetahuan, meningkatkan soft skill dan hard skill, mengembangkan daya inovasi dan mencukupi kebutuhan profesi tertentu. Program diklat didalam dan diluar dilaksanakan secara tertur, terencana dan terintegrasi dengan program rumah sakit. Kegiatan di dalam rumah sakit wajib diikuti oleh setiap karyawan, dimana pelaksanaannya diatur sedemikian rupa sehingga tidak mengganggu pelayanan rumah sakit.

Rumah sakit memberikan pelatihan rutin yang diikuti oleh karyawan. Tujuan pelatihan ini untuk meningkatkan kemampuan karyawan dalam bekerja, memberikan pengarahan dalam bekerja, serta memberikan informasi tentang jenjang karir untuk para karyawan.

Adanya pelatihan dan pengembangan yang diadakan rumah sakit maupun lembaga lainnya diharapkan karyawan dapat meningkatkan kinerjanya dan semangat dalam bekerja serta mampu menyelesaikan permasalahan kerjanya sehingga kinerja karyawan mampu ditingkatkan.

\section{Sistem Kompensasi}

Sistem penggajian berdasarkan sistem penggajian pemerintah dan sesuai dengan UMR Kabupaten Kebumen. Karyawan diberikan penghargaan finansial seperti tunjangan kesehatan, tunjangan keluarga, gaji berkala, dan THR. Tunjangan non finansial berupa pelatihan, pendidikan, dan cuti. Kebijakan sistem penggajian telah sesuai dengan kebutuhan dasar dan telah memotivasi karyawan.

Mekanisme pembayaran gaji di RSUD Dr. Soedirman adalah dilakukan pada tanggal 1 setiap bulannya, dan dibayarkan maksimal tanggal 5. Gaji yang dibayarkan berdasarkan posisi dari masing-masing karyawan.

Dasar penggajian karyawan rumah sakit menunjukan penggolongan gaji secara berjenjang berdasarkan pendapatan tetap (gaji pokok, premi tetap, tunjangan) dan 
pendapatan tidak tetap ( jasa layanan, remunerasi, bonus, THR, dan pendidikan diluar kompensasi dan gaji tetap). Gaji ditinjau dan direvisi secara berkala oleh manajemen.

\section{Penilaian Prestasi Kerja}

RSUD Dr. Soedirman akan memberikan reward bagi karyawan yang mempunyai dedikasi tinggi terhadap rumah sakit, memiliki kedisiplinan yang tinggi, dan kepatuhan terhadap aturan yang berlaku. Manajemen rumah sakit akan memberikan reward berupa fasilitas yang menunjang pekerjaan karyawa.

Terkait dengan punishment di RSUD Dr. Soedirman tidak ada toleransi untuk kegiatan atau pekerjaan karyawan yang tidak sesuai dengan aturan. Misalkan keterlambatan hadir lebih satu menit dari jam kerja yang telah ditentukan, akan mendapat sanksi berupa pengurangan satu point reward.

Jumlah point penilaian untuk masing-masing karyawan berdasarkan lamanya masa kerja, ketepatan waktu hadir, banyaknya jam pendidikan dan pelatihan, fungsi struktural, fungsi fungsional, ketaatan pada aturan, dan penilaian lainnya.

\section{Pemutusan Hubungan Kerja}

Pemutusan hubungan kerja yang ada di RSUD Dr. Soedirman adalah ketika karyawan yang dikontrak selama satu tahun tidak menunjukan perkembangan yang berarti. Apabila karyawan tidak masuk kerja selama tiga hari berturut-turut tanpa izin atau keterangan yang jelas, maka akan dilakukan pemutusan hubungan kerja atau langsung dikeluarkan dari rumah sakit.

Bentuk punishment terkait dengan Pemutusan Hunungan Kerja dilakukan ketika karyawan melakukan kecurangan atau kegiatan lainnya yang merugikan rumah sakit.

\section{Peran Audit Manajemen}

Audit manajemen dapat dilakukan oleh manajemen. Audit manajemen rumah sakit pada umumnya dilakukan oleh auditor internal atau dapat juga dilakukan oleh auditor eksternal yang ditunjuk untuk memeriksa kegiatan dari rumah sakit. Audit manajemen bertujuan untuk mengevaluasi efektivitas dan efisien operasi serta melaporkan hasilnya kepada direktur dan pihak yang berkepentingan terhadap tata kelola rumah sakit disertai dengan rekomendasi maupun saran perbaikan.

Audit manajemen dapat dipandang sebagai suatu bentuk kritik yang membangun disertai saran dan rekomendasi yang dapat diterapkan pada rumah sakit secara keseluruhan. Penerapan audit manajemen juga bisa dilakukan pada bagian tertentu suatu rumah sakit untuk meningkatkan proses operasional sesuai dengan kebutuhan.

Audit manajemen ini lebih ditekankan pada kegiatan pelayanan 
kesehatan yang bertujuan untuk memeriksa apakah kebijakan, prosedur, dan kegiatan pelayanan kesehatan sudah mencapai tujuan yang diterapkan manajemen dan apakah tujuan tersebut dicapai dengan cara yang terbaik dan ekonomis.

Pada laporan akhir audit manajemen akan mencantumkan temuan dan rekomendasi sebagai masukan kepada direktur untuk mengatasi kelemahan yang ada, serta upaya-upaya yang dapat dilakukan menuju perbaikan yang diharapkan. Selain itu, audit manajemen dapat membantu manajemen dalam melaksanakan kegiatan operasional rumah sakit, khususnya pelayanan kesehatan Rawat Inap dengan lebih efektif dan efisien.

RSUD Dr. Soedirman mempunyai audit internal atau audit manajemen yang disebut Sistem Pengawasan Internal (SPI) dimana audit internal ini bertugas mengawasi dan mengevaluasi seluruh kegiatan pelayanan yang ada di rumah sakit. Aktivitas lain yang dilakukan oleh Sistem Pengawasan Internal (SPI) memberikan saran atau masukan kepada direktur yang berhubungan dengan perkembangan pelayanan RSUD Dr. Soedirman. RSUD Dr. Soedirman juga diperiksa oleh auditor eksternal, yaitu Badan Pemeriksa Keuangan (BPK) terkait dengan pelayanannya.

Ringkasan Hasil Pembahasan Analisis

\begin{tabular}{|l|r|r|}
\hline \multicolumn{1}{|c|}{ Model } & Coefficients & \multicolumn{1}{c|}{ Sig. } \\
\hline (Constant) & & .095 \\
\hline Kualifikasi & .223 & .017 \\
\hline Program & .409 & .000 \\
\hline Pelaksanaan & .185 & .042 \\
\hline Tindak lanjut & -.115 & .227 \\
\hline
\end{tabular}

Dari tabel di atas dapat diketahui bahwa kualifikasi auditor, program audit, dan pelaksanaan audit menunjukkan signifikansi berturut-turut 0,017;0,000;0,042 (dibawah 0,005) dan koefisien menunjukkan nilai positif sehingga dapat disimpulkan bahwa $\mathrm{H} 1, \mathrm{H} 2$, dan $\mathrm{H} 3$ terdukung. Namun, tindak lanjut audit menunjukkan signifikansi 0,227 (di atas 0,005) dan koefisien menunjukkan nilai negatif sehingga $\mathrm{H} 4$ tidak terdukung.

\section{PENUTUP}

\section{Keterbatasan}

Keterbatasan dalam penelitian ini adalah:

1. Keterbatasan dalam waktu penelitian sehingga peneliti dan responden tidak terlalu intens berkomunikasi

2. Tidak menutup kemungkinan data yang diberikan reponden bersifat bias karena penelitian ini berdasarkan pengukuran sikap skala likert yang disampaikan secara tertulis dalam bentuk kuisioner

\section{Saran}


1. Penulis menyarankan kepada auditor internal RSUD Dr. Soedirman Kebumen dalam melaksanakan audit dapat memahami fungsinya sebagai auditor sesuai dengan standar yang telah ditetapkan

2. Penulis menyarankan kepada auditor internal RSUD Dr. Soedirman Kebumen agar terus meningkatkan independensi, integritas, dan skeptisisme dalam melaksanakan audit

\section{DAFTAR PUSTAKA}

Alien, Firstie Ulya., Audit Manajemen Atas Fungsi Sumber Daya Manusia Pada RSU Permata Blora. Skripsi S1 Jurusan Pendidikan Akuntansi, Fakultas Ekonomi Universitas Negeri Yogyakarta, 2014

Aminuddi, M. Yusuf., Audit SDM Pada Dinas Pendidikan Pemuda dan Olahraga Kabupaten Ende. Sekolah Tinggi Agama Islam Al-Hikmah Tuban

Annisa, Pramudya Nu., dan Mustikawati, Rr. Indah., Pengaruh Audit Manajemen Sumber Daya Manusia Terhadap Kinerja Karyawan Di Rumah Sakit umum Purbowangi (Human Resources Management Audit on Employee Performance in Purbowangi Hospital). Prodi Akuntansi dan Staf Pengajar Jurusan
Pendidikan Akuntansi Universitas Negeri Yogyakarta, 2015

Arvianita, Rezki Retno., Pengaruh Audit Operasional dan Pengendalian Internal Terhadap Efektivitas Pelayanan Kesehatan pada Rumah Sakit (Studi Kasus pada Rumah Sakit Umum Queen Latifa Yogyakarta). Skripsi S1 Fakultas Ekonomi Universitas Negeri Yogyakarta, 2015 Bayangkara., Audit Manajemen, Jakarta, Salemba Empat

Dismawati, Lina Rizki., Peerapan Audit Manajemen Sumber Daya Manusia Untuk Menilai Kinerja pada Bank Maspion. Sekolah Tinggi Ilmu Ekonomi Indonesia (STIESIA)

Divianto., Peranan Audit Operasional Terhadap Efektivitas Pelayanan Kesehatan Rawat Inap di Rumah Sakit (Studi Kasus pada Rumah Sakit Bunda Palembang). Politeknik Negeri Sriwijaya Palembang, 2012

Fahmi, Irfan., Pengantar Manajemen Sumber Daya Manusia Konsep dan Kinerja, Edisi Pertama, Jakarta, Mitra Wacana Media, 2016

Hariyanto, Resa., Audit Manajemen Sebagai Sarana Untuk Menilai Efektivitas Fungsi Sumber Daya Manusia (Studi Kasus Pada PT. Bank Rakyat Indonesia Cabang Pasuruan). 
Haryono, Jusup., Auditing, Yogyakarta, Sekolah Tinggi Ilmu Ekonomi YKPN, 2001

Institut Akuntan Publik Indonesia., Standar Audit, Jakarta, Salemba Empat, 2013 Keputusan Menteri Keuangan Republik Indonesia No. 340/MENKES/PER/III/2010

Malayu., Manajemen Sumber Daya Manusia, Jakarta, PT. Bumi Aksara, 2005

Nasution, Yolanda,. dan Prasetya, Arik., Audit Manajemen Untuk Menilai Kinerja Fungsi SDM (Studi pada Fungsi Rekrutmen-SeleksiOrientasi,Pelatihan dan Pengembangan, Penilaian Prestasi Kerja, dan Pemutusan Hubungan Kerja PT. XYZ Indonesia-Medan). Fakultas Ilmu Administrasi Universitas Brawijaya, Malang

Peraturan Menteri Kesehatan Republik Indonesia Nomor 56 Tahun 2014 tentang Klasifikasi dan Perijinan Rumah Sakit

Pradana, Riska Agustin Widya., dan Fachriyah, Nurul., Audit Manajemen Untuk Menilai Efektivitas Fungsi Sumber Daya Manusia (Studi Kasus pada Rumah Sakit Islam Aisyiyah Malang). Skripsi S1 Fakultas Ekonomi dan Bisnis Universitas Brawijaya
Saragih, D. Yohansen., Peranan Audit Operasional Dalam Mendorong Efektivitas Pelayanan Kesehatan Unit Gawat Darurat Di Rumah Sakit (Studi Kasus pada Perjan Rumah Sakit Dr. Hasan Sadikin). Skripsi S1 Jurusan Akuntansi, Fakultas Ekonomi, Universitas Widyatama Septianingrum, Elisa., Pengaruh Audit Manajemen Terhadap Kinerja Karyawan Pada PT. Bank Panin Tbk Cabang Kendari. Jurusan Akuntansi, Fakultas Ekonomi dan Bisnis, Universitas Halu Oleo Kendari, Sulawesi Tenggara

Undang-Undang Republik Indonesia No. 44 Tahun 2009 tentang Rumah Sakit Zamzani, Faiz., Ihda Arifin Faiz., dan Mukhlis., Audit Internal Konsep dan Praktik, Cetakan Ketiga, Yogyakarta, Gadjah Mada University Press, 2017 